\title{
Concentration of some heavy metals in Egyptian human hair
}

\author{
A.B. El - Bialy ${ }^{1}{ }^{*}$, S.S Hamed ${ }^{1}$, S.Abd El-Mongy ${ }^{1}$, E. Abd El Aziz. Mohamed ${ }^{2}$ \\ ${ }^{1}$ Physics Department, University collage for Women for Arts, Science and Education, Ain Shams University \\ ${ }^{2}$ Higher Institute of Engineering and Technology in new Cairo \\ *Corresponding author_E-mail:samiraabd_32@yahoo.com
}

Copyright $(2014$ A.B. El - Bialy et al. This is an open access article distributed under the Creative Commons Attribution License, which permits unrestricted use, distribution, and reproduction in any medium, provided the original work is properly cited.

\begin{abstract}
In this work, Flame Atomic Absorption Spectrometry (FAAS) was applied for the determination of $\mathrm{Cu}, \mathrm{Fe}, \mathrm{Mg}, \mathrm{Mn}, \mathrm{Ni}$, and $\mathrm{Zn}$ in twenty -four hair samples. The samples were collected covering different ages and gender. The samples are divided as, seventeen samples from people which assumed to be environmentally healthy (control) and seven samples from different worker's people such as Iron worker, Cement worker and Duco worker (exposed). Samples were brought into solution using $\mathrm{HNO}_{3}$ and $\mathrm{H}_{2} \mathrm{O}_{2}$. In three example samples the molecular structure of the human hair was studied using Fourier Transformer Infrared Spectrometer (FTIR) in the range of $200-4000 \mathrm{~cm}^{-1}$. The contamination of the sample was discussed for different samples.
\end{abstract}

Keywords: Human Hair, Heavy Metals, FAAS, FTIR.

\section{Introduction}

In the last few decades the analytical study of concentrations of the minor and trace elements in biological and human samples have become very important. Occupational diseases, poisoning, and environmental diseases are accurately diagnosed by using trace elemental analysis of human biological samples and the state of health can be characterized with the analytical results[1]. The importance of these examinations is attested to by the fact that there are several trace elements in the human body that are important in the biochemical processes. An excess or absence of these essential trace elements causes serious problems in the physiology of the body. Thus, it is very important to check regularly trace element Concentrations in the body. Trace element analysis of biological samples is a considerable challenge to analytical studies.

The accurate and sensitive determinations of trace elements are the important part of analytical chemistry studies. [2-4] Flame atomic absorption spectrometry (FAAS) is relatively simple and available technique in many laboratories for heavy metal determination. [5-10] Because of the large amount of organic substances in the samples, digestion or ashing is required prior to analysis and the low concentrations of the measured elements demand well-organized [11] Interest in human hair as a clinical sample has increased in recent years due to certain advantages offered by human hair over other clinical specimens such as blood or urine samples. Hair offers a good way of discerning long-term variations in trace element concentration by providing a better assessment of normal trace element concentrations [12].

The advantages of analysis of hair over blood and urine samples for the determination of metals are (I) the concentrations of most of the trace elements are higher in hair than in other human materials; (II) specimens can be collected more quickly and easily than specimens of blood, urine or any other tissue and also special storage conditions are not needed; (III) unlike blood, hair is an inert and chemically homogeneous sample ; and (IV) serum and urine concentrations provide both an acute index and also over a relatively short time period whereas the concentrations in hair provide a retrospective index of trace element supplies[13] .

Keratin is one of the most abundant proteins, being the major component of hair, feathers, nails and horns of mammals, reptiles and birds. The disposal of keratin wastes such as fiber byproducts from the wool textile industry, poor quality raw wools not fit for spinning, horns, nails and feathers from butchery, involve complex environmental and economic aspects. Moreover, pooling and processing of keratin wastes could allow a better exploitation of such a large amount of biomass, considering that the total amount of these materials has been estimated more than 3 million tons per year [14]. 
The essential element of the structure of the keratin macromolecule is the way of alignment of amino acids residue along its chain. The sequence of amino acids defines the possibility of intermolecular links, the molecular cohesion of the keratin and the access of amino acids to the chemical reaction [15].

The aim of the present work is to determine the concentration of heavy metals in human hair and its molecular structure.

\section{Experimental}

\subsection{Sample preparation}

To remove the external contamination from samples, washing technique should be applied such that it will remove only the surface external contamination without extracting metals from the samples or depositing metals on them. According to Harrison and Tyree [16] detergent washing reduced the element concentrations more than the organic washing. However for heavy metals, washing procedures do not essentially influence their concentrations because of the strong complex with the disulfide groups in keratin proteins [17]. Therefore, acetone was used in this study as washing liquid to remove the external contaminates. The samples were cut in pieces as small as possible, washed three times with acetone, and rinsed three times with deionized water. After washing, the hair samples were dried in an electric oven $60^{\circ} \mathrm{c}$ and protected in polyethylene bags until analysis.

Apportion of $0.5 \mathrm{gm}$ of the dried sample weight in a clean glass beaker, followed with $20 \mathrm{ml}\left(\mathrm{HNO}_{3}\right)$ and $10 \mathrm{ml}$ $\left(\mathrm{H}_{2} \mathrm{O}_{2}\right)[12]$. It was heated gently on a hot plate at $150^{\circ} \mathrm{C}$ until evaporated to near dryness for three hours. Further $10 \mathrm{ml}$ of $\mathrm{HNO}_{3}$ and $10 \mathrm{ml}$ hydrogen peroxide $\left(\mathrm{H}_{2} \mathrm{O}_{2}\right)$ were added to the residue and evaporated to near dryness to ensure the complete dissolution. Distilled water is then added to the sample, and completed to $50 \mathrm{ml}$, in a volumetric flask to obtain a clear solution.

For IR study the samples were measured using $\mathrm{KBr}$ disc technique. $200 \mathrm{mg}$ of (KBr) mixed with sample and pressed under pressure 10 tons held for 5 minutes and then slowly released a disc diameter of $13 \mathrm{~mm}$.

\section{Apparatus}

Thermo-Elemental S4 full automatic atomic absorption spectrometer equipped with deuterium continuum background corrector. A burner-nebulizer (100 mm with single slot for air acetylene $\left.\mathrm{C}_{2} \mathrm{H}_{2}\right)$ was utilized as an absorption cell. The light sources were Thermo- Elemental hollow cathode lamps. All measurements were the average of three $3 \mathrm{~s}$ integrations and a blank measurement was made between every solution measurement. Jasco 300E Fourier transform infrared spectrometer was used in the present work.

\section{Results and discussion}

\subsection{Concentration of determined elements}

In order to construct the analytical calibration curve standard solutions in increasing concentration were nebulized at the operating conditions (according to manufacture guide). The absorbance were determined and plotted against the concentrations. Under the same operating conditions, the sample solutions were nebulized and the absorbance was determined. It would be mentioned here that the determined absorbance is the value after reject incompatible readings (incompatible reading means scattering more than 95\%). Obtained concentrations of the determined elements in hair samples for control and worker group are present in Tables 1 and 2 . The values listed are the mean values of ten replicate determinations.

It was observed from the obtained results that the concentration of the determined elements $(\mathrm{Cu}, \mathrm{Fe}, \mathrm{Mg}, \mathrm{Mn}, \mathrm{Ni}$ and $\mathrm{Zn}$ ) in samples of control group is lower than the obtained one of worker's. The higher concentration for metals in worker's hair may be due to contamination from their area. Also it was observed that the average concentration for all elements in all ages for hair samples of Duco worker's is higher, except for $\mathrm{Zn}$. The average concentration of $\mathrm{Zn}$ in hair samples for Iron workers is higher than the average concentration of other elements in Duco and Cement worker's hair samples.

\section{Metal concentration in relation to ages}

The relation between the concentration of the determined elements in control hair samples and their ages are illustrated in Fig $(1,2)$. It was observed that the behaviors of $\mathrm{Cu}, \mathrm{MN} \mathrm{Ni} \mathrm{Zn}$ and $\mathrm{Mg}$ are similar, but the concentration of Fe at age 30 years decreases. This may be due to the manner of the nutrition of the donor's at this age. 
Table 1: Concentration in ppb for Detected Elements in Human Hair for (Control Group)

\begin{tabular}{|c|c|c|c|c|c|c|c|}
\hline \multirow[t]{2}{*}{ sample } & \multirow[t]{2}{*}{ Age (year) } & \multicolumn{6}{|c|}{ Concentration in ppb } \\
\hline & & $\mathrm{Cu}$ & $\mathrm{Fe}$ & $\mathrm{Mg}$ & $\mathrm{Mn}$ & $\mathrm{Ni}$ & $\mathrm{Zn}$ \\
\hline 1 & 6 & $151 \pm 7$ & $5018 \pm 251$ & $2167 \pm 108$ & $163 \pm 8$ & $514 \pm 25$ & $1353 \pm 68$ \\
\hline 2 & 10 & $100 \pm 5$ & $4754 \pm 238$ & $6207 \pm 310$ & $163 \pm 8$ & $500 \pm 25$ & $1937 \pm 97$ \\
\hline 3 & 14 & $112 \pm 5$ & $4441 \pm 222$ & $2760 \pm 138$ & $200 \pm 10$ & $517 \pm 25$ & $1995 \pm 100$ \\
\hline 4 & 15 & $122 \pm 6$ & $4425 \pm 221$ & $3039 \pm 152$ & $137 \pm 7$ & $535 \pm 27$ & $1933 \pm 97$ \\
\hline 5 & 20 & $98 \pm 5$ & $6375 \pm 319$ & $4286 \pm 214$ & $262 \pm 13$ & $561 \pm 28$ & $1652 \pm 83$ \\
\hline 6 & 21 & $162 \pm 8$ & $2548 \pm 127$ & $3660 \pm 138$ & $174 \pm 9$ & $578 \pm 29$ & $1877 \pm 94$ \\
\hline 7 & 24 & $114 \pm 6$ & $3359 \pm 168$ & $3355 \pm 168$ & $225 \pm 11$ & $742 \pm 37$ & $2023 \pm 101$ \\
\hline 8 & 26 & $130 \pm 7$ & $2381 \pm 119$ & $4104 \pm 205$ & $225 \pm 11$ & $618 \pm 31$ & $2077 \pm 104$ \\
\hline 9 & 27 & $125 \pm 6$ & $4337 \pm 217$ & $3976 \pm 199$ & $350 \pm 17$ & $519 \pm 26$ & $1937 \pm 97$ \\
\hline 10 & 28 & $151 \pm 8$ & $3190 \pm 159$ & $2742 \pm 137$ & $137 \pm 7$ & $506 \pm 25$ & $1639 \pm 82$ \\
\hline 11 & 35 & $121 \pm 6$ & $4645 \pm 232$ & $3849 \pm 142$ & $163 \pm 8$ & $494 \pm 24$ & $1709 \pm 85$ \\
\hline 12 & 36 & $108 \pm 5$ & $2067 \pm 103$ & $3840 \pm 142$ & $137 \pm 7$ & $487 \pm 24$ & $1606 \pm 80$ \\
\hline 13 & 37 & $142 \pm 7$ & $5024 \pm 251$ & $2975 \pm 149$ & $163 \pm 8$ & $482 \pm 24$ & $1750 \pm 88$ \\
\hline 14 & 45 & $118 \pm 6$ & $5932 \pm 297$ & $2285 \pm 114$ & $112 \pm 6$ & $528 \pm 26$ & $1898 \pm 95$ \\
\hline 15 & 48 & $108 \pm 5$ & $2138 \pm 107$ & $3512 \pm 176$ & $163 \pm 8$ & $490 \pm 24$ & $1782 \pm 89$ \\
\hline 16 & 50 & $125 \pm 6$ & $4982 \pm 249$ & $3461 \pm 173$ & $157 \pm 5$ & $441 \pm 22$ & $1605 \pm 80$ \\
\hline 17 & 66 & $155 \pm 8$ & $4046 \pm 202$ & $4427 \pm 221$ & $163 \pm 8$ & $454 \pm 23$ & $1734 \pm 87$ \\
\hline sample & $\begin{array}{c}\text { Age } \\
\text { (year) }\end{array}$ & & & Concentratio & in $\mathrm{ppb}$ & & \\
\hline & & $\mathrm{Cu}$ & $\mathrm{Fe}$ & $\mathrm{Mg}$ & $\mathrm{Mn}$ & $\mathrm{Ni}$ & $\mathrm{Zn}$ \\
\hline 1 & 32 & $193 \pm 10$ & $6935 \pm 347$ & $6657 \pm 333$ & $138 \pm 7$ & $491 \pm 25$ & $3445 \pm 172$ \\
\hline 2 & 36 & $263 \pm 18$ & $6900 \pm 345$ & $5579 \pm 280$ & $371 \pm 19$ & $454 \pm 23$ & $1765 \pm 88$ \\
\hline 3 & 13 & $212 \pm 11$ & $7967 \pm 398$ & $6228 \pm 311$ & $288 \pm 14$ & $466 \pm 23$ & $2353 \pm 118$ \\
\hline 4 & 30 & $292 \pm 15$ & $6468 \pm 323$ & $6086 \pm 304$ & $725 \pm 36$ & $462 \pm 23$ & $3261 \pm 163$ \\
\hline 5 & 44 & $200 \pm 11$ & $6375 \pm 319$ & $5770 \pm 289$ & $230 \pm 12$ & $472 \pm 24$ & $1497 \pm 75$ \\
\hline 6 & 16 & $508 \pm 25$ & $7960 \pm 398$ & $6038 \pm 302$ & $525 \pm 26$ & $542 \pm 27$ & $2324 \pm 116$ \\
\hline 7 & 25 & $350 \pm 18$ & $7245 \pm 362$ & $7154 \pm 358$ & $500 \pm 25$ & $453 \pm 23$ & $2548 \pm 123$ \\
\hline
\end{tabular}

iron worker $(1,2)$ - cement worker $(3,4,5)$-duco worker $(6,7)$.

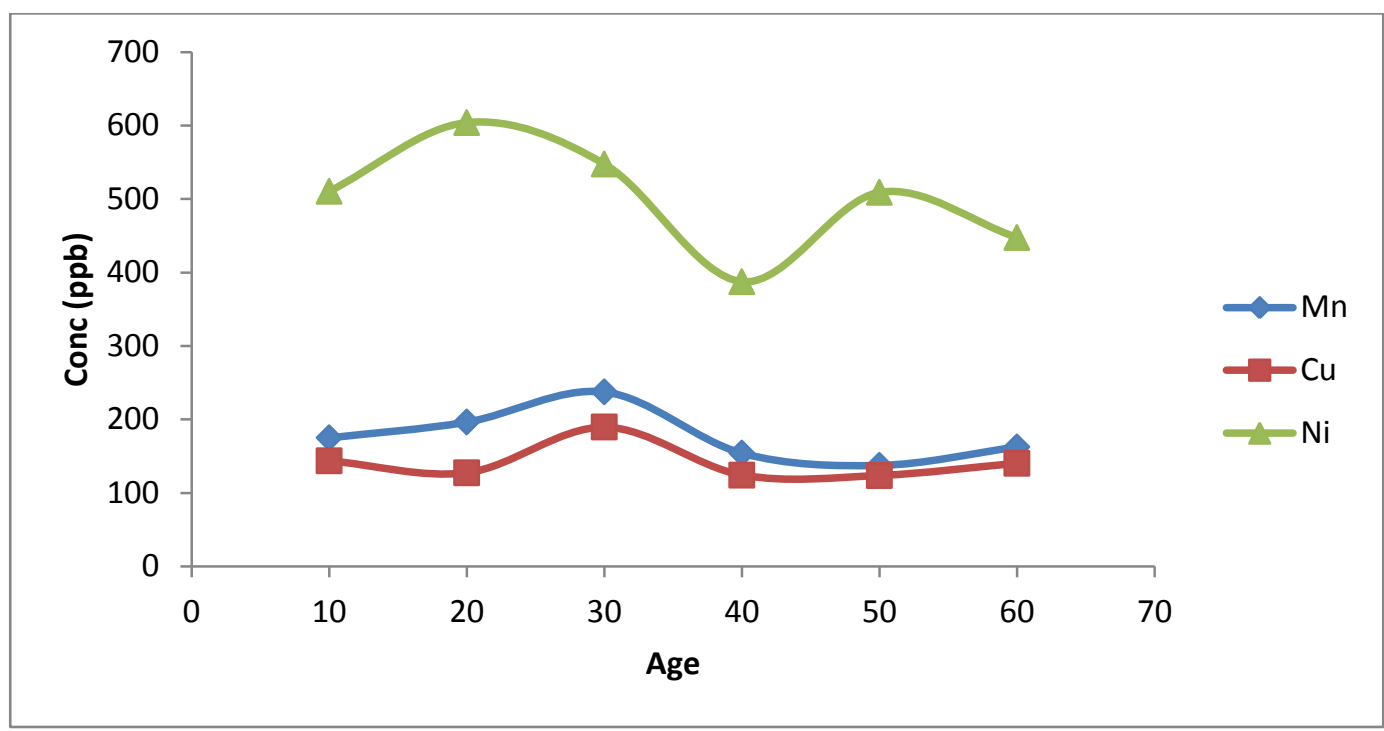

Fig. 1: Relation between Ages of Human Hair and Metal Concentration $(\mathrm{Cu}, \mathrm{MN}$ and $\mathrm{Ni})$ 


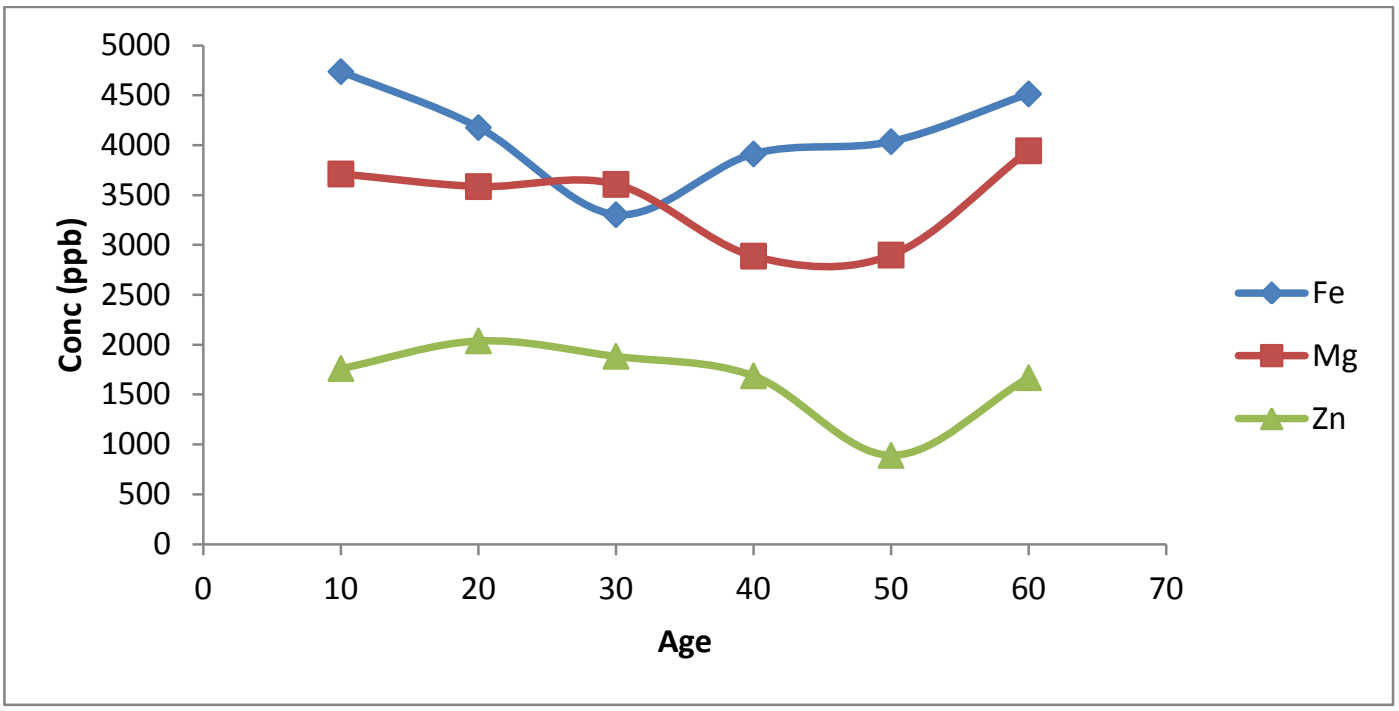

Fig. 2: Relation between Ages of Human Hair and Metal Concentration (Fe, MN and Zn).

\section{FTIR spectra of hair samples}

The infrared absorption spectra for control and worker hair samples were measured in the wavenumber ranging from 200- $4000 \mathrm{~cm}^{-1}$. The spectra were recorded in two ranges from $200-400 \mathrm{~cm}^{-1}$ and $400-4000 \mathrm{~cm}^{-1}$ Fig. (3, 4) respectively. In Fig. (3) A new band appeared at $230,219 \mathrm{~cm}^{-1}$ in worker sample (b,c), this band may be due to M- N stretching vibration indicating the interaction between the metal and nitrogen atom. Fig. (4a) shows a strong and medium absorption bands appeared at 3785 and $3323 \mathrm{~cm}^{-1}$, these bands due to $\mathrm{N}-\mathrm{H}$ stretching vibration symmetric and asymmetric. The first one shifted to lower wavenumber in Fig. (4 b, c ), it appeared at $3778,3781 \mathrm{~cm}^{-1}$ respectively, but the band at $3323 \mathrm{~cm}^{-1}$ is shifted to higher wavenumber in (b, c) it appeared at $3413,3424 \mathrm{~cm}^{-1}$ respectively. Due to C-H bending in - plane, strong band appeared at $1440 \mathrm{~cm}^{-1}$ Fig. (4a), this band appeared at $1432 \mathrm{~cm}^{-1}$ Fig. (4b). A band appeared at $652 \mathrm{~cm}^{-1}$ in Fig. (4a) which characteristic to C-H rocking vibration shifted in Fig. (4b, c) to higher wavenumber it appeared at $668,775 \mathrm{~cm}^{-1}$. An absorption band appeared at $1812 \mathrm{~cm}-1$ of strong intensity assigned to $\mathrm{C}=\mathrm{O}$ stretch vibration Fig. (4a) is shifted to lower wavenumber in Fig. (4b, c) and appeared at $1629-1710 \mathrm{~cm}^{-1}$. This shift is due to the interaction between oxygen of the carbonyl group and metal. In control hair sample Fig. (4a) band appeared at $543 \mathrm{~cm}^{-1}$ which related to C-C bending vibration is shifted to higher wavenumber in worker hair samples (4 b, c) and appeared at $592,568 \mathrm{~cm}^{-1}$.

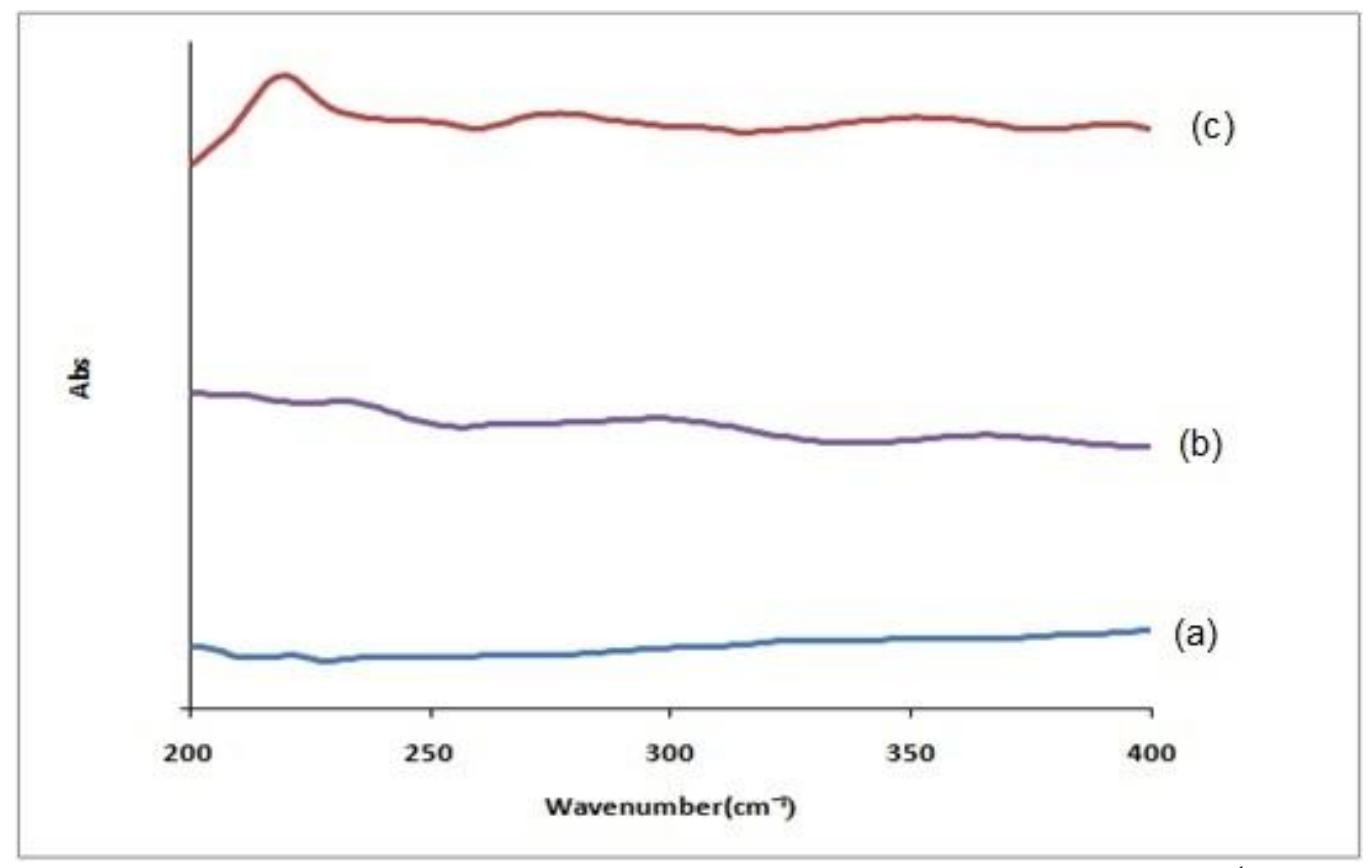

Fig. 3: FTIR Spectrum of (A) Control Sample and (B, C) Worker Hair in the Range (200-400) $\mathrm{Cm}^{-1}$ 


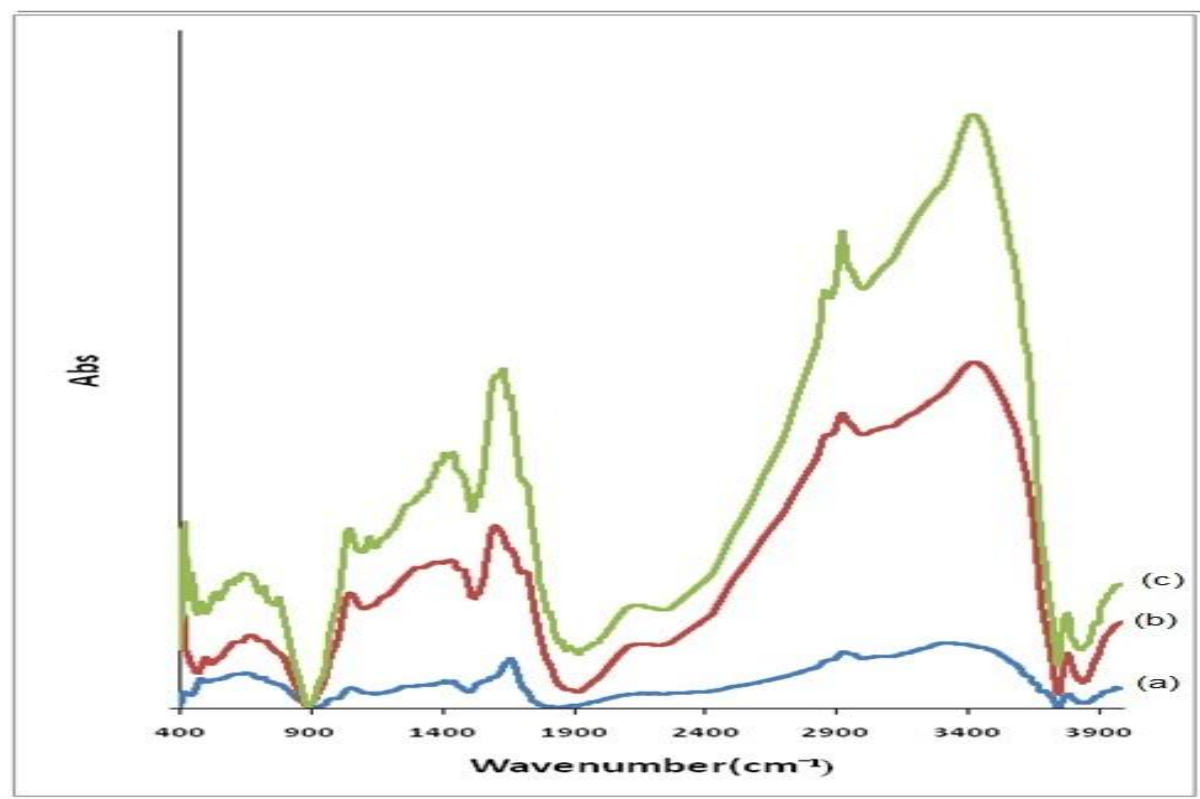

Fig. 4: FTIR Spectrum of (A) Control Sample and Worker Hair in the Range (400-4000) $\mathrm{Cm}^{-1}$

To indicates, the existence of interaction between metal in worker hair samples and both oxygen and nitrogen in keratin, the ratio $\left(\mathrm{R}_{1}, \mathrm{R}_{2}\right)$ the absorbance of the $\mathrm{N}-\mathrm{H}$ band at $3323 \mathrm{Cm}^{-1}$ and $\mathrm{C}=\mathrm{O}$ band at $1812 \mathrm{Cm}^{-1}$ to $\mathrm{C}-\mathrm{H}$ band at $2927 \mathrm{Cm}$ was calculated. The $\mathrm{C}-\mathrm{H}$ band at $2927 \mathrm{Cm}^{-1}$ was taken as a reference in the ratios $\mathrm{R}_{1}$ and $\mathrm{R}_{2}$ since this band is not affected by contamination. The results are illustrated in Table (3).

Table 3: The Absorbance Ratios $\mathrm{R}_{1}$ and $\mathrm{R}_{2}$ for the Worker Hair Samples

\begin{tabular}{lll}
\hline Sample & $(\mathrm{N}-\mathrm{H} / \mathrm{C}-\mathrm{H})$ & $(\mathrm{C}=\mathrm{O} / \mathrm{C}-\mathrm{H})$ \\
\hline & $\mathrm{R}_{1}$ & $\mathrm{R}_{2}$ \\
(a) & 1.1634 & 0.054116 \\
(b) & 1.737 & 0.69031 \\
(c) & 2.60285 & 1.49017 \\
\hline
\end{tabular}

\section{Conclusion}

The results obtained for the concentrations of metal in different samples of human hair reviled that the concentration of these elements for all worker's hair samples are significantly higher than the control samples. Also no clear correlation was observed for the ages or gender.

The limits of detection lie between $0.066 \mathrm{ppb}$ for $\mathrm{Mg}$ to $0.012 \mathrm{ppb}$ for $\mathrm{Zn}$. The values obtained for precision lie between $0.2 \%$ to $3.1 \%$ for $\mathrm{Mg}$ and $\mathrm{Zn}$ respectively indicates the reliability.

The results obtain from atomic spectrometric techniques agree very well with the results obtained from FTIR.

The presence of the studied heavy metals in human hair depend on environmental exposure .This study proved that human scalp hair could be used successfully as a biological indicator for the assessment of heavy metal pollution.

\section{References}

[1] I.Hassan, G.Tasneem, B. Dermot, and N.Sumsun, Interaction between zinc, cadmium, and lead in scalp hair samples of Pakistani and Irish smokers rheumatoid arthritis subjects in relation to controls, Biomedical and Life Sciences, vol.148, number 2 (2012), $139-147$.

[2] A.Duran, M.Tuzen, M.Soylak, Trace element concentrations of some pet foods commercially available in Turkey Food Chem. Toxicol. 48, (2010), 2833. http://dx.doi.org/10.1016/j.fct.2010.07.014.

[3] F.Kabadayi, H.Cesur, Determination of Cu, Pb, Zn, Ni, Co, Cd, and Mn in road dusts of Samsun City Environ. Monit. Assess. 168, (2010), 241. http://dx.doi.org/10.1007/s10661-009-1108-1.

[4] I.Koyuncu, N .Akcin, G.Akcin, K.Mutlu, Comparative Study of Ion-exchange and Flotation Processes for the Removal of Cu2+ and Pb2+ Ions from Natural Waters, Rev. Anal. Chem. 29,(2010), 93. http://dx.doi.org/10.1515/REVAC.2010.29.2.93.

[5] M.Tuzen, M Melek, M.Soylak, J. Hazard. Mater. Coprecipitation of Ni2+, Cd2+ and Pb2+ for preconcentration in environmental samples prior to flame atomic absorption spectrometric determinations 159,(2008), 335. http://dx.doi.org/10.1016/j.jhazmat.2008.02.021.

[6] G. A.Kandhro, T. G.Kazi,. J. A Baig, H. I.Afridi, A. Q.Shah, H. R.Sheikh, N. F.Kolachi, S. K.Wadhwa, Zinc and Iron Determination in Serum and Urine Samples of Thyroid Patients Using Cloud Point Extraction J. AOAC Int. 93,(2010), 1589.

[7] J.Abulhassani, J. L.Manzoori, M.Amjadi, Hollow fiber based-liquid phase microextraction using ionic liquid solvent for preconcentration of lead and nickel from environmental and biological samples prior to determination by electrothermal atomic absorption spectrometry, J. Hazard. Mater. 176,(2010), 481. http://dx.doi.org/10.1016/j.jhazmat.2009.11.054. 
[8] Q.He, Z.Hu, Y.Jiang, X.Chang, Z.Tu, L.Zhang, Preconcentration of $\mathrm{Cu}(\mathrm{II})$, Fe(III) and Pb(II) with ((2-aminoethylamino)methyl)phenol-functionalized activated carbon followed by ICP-OES determination.J. Hazard. Mater. 175, (2010), 710. http://dx.doi.org/10.1016/j.jhazmat.2009.10.067.

[9] V. A.Lemos, L. N. Santos, M. A.; M. A. Bezerra, Determination of cobalt and manganese in food seasonings by flame atomic absorption spectrometry after preconcentration with 2-hydroxyacetophenone-functionalized polyurethane foamJ. Food Compos. Anal. 23, (2010), 277. http://dx.doi.org/10.1016/j.jfca.2009.11.004.

[10] L.Zhang, X.Chang, Z.Li, Q.He, Selective solid-phase extraction using oxidized activated carbon modified with triethylenetetramine for preconcentration of metal ions, J. Mol. Struct. 964, (2010), 58 http://dx.doi.org/10.1016/j.molstruc.2009.11.009.

[11] J.Dombová and L. papp, Comparison of Sample Preparation Methods for Elemental Analysis of Human Hair ,Microchemical, 59, (1998), 187-193. http://dx.doi.org/10.1006/mchj.1998.1573.

[12] K. S. Rao, T. Balaji, T.P.Rao,Y.Babu and G.R.K.Naidu, Determination of iron, cobalt, nickel, manganese, zinc, copper, cadmium and lead in human hair by inductively coupled plasma-atomic emission spectrometry, Spectrochimica Acta Part B, 57, (2002), 1333-1338. http://dx.doi.org/10.1016/S0584-8547 (02)00045-9.

[13] J. Md Khudzari, H. Wagiran, Md. I. Hossain, N. Ibrahim and M. A. Agam, Heavy metals Mn, Fe, Ni, Cu and Zn in human hair samples using energy dispersive X-ray fluorescence analysis, International Journal of the Physical Sciences, Vol. 6(8),( 2011), pp. $2090-2094$.

[14] A.Aluigi, M.Zoccola, C.Vineis, C.Tonin, F Ferrero and M. Cantti, Study on the structure and properties of wool keratin regenerated from formic acid, international Journal of Biological Macromolecules, 41,(2007), 266-273.

[15] E.Wojciechowska,A.Włochowicz and A.W.Birczyńska, Application of Fourier-transform infrared and Raman spectroscopy to study degradation of the wool fiber keratin, Journal of Molecular Structure, 511-512, (1999), 307-318.

[16] W.W.Harrison and A. B.Tyree, The determination of trace elements in human fingernails by atomic absorption spectroscopy, ClinChima Acta, 31,(1971),63-73. http://dx.doi.org/10.1016/0009-8981 (71)90362-7.

[17] M.N.Rashed and F. hossam, Heavy Metals in Fingernails and Scalp Hair of Children, Adults and Workers from Environmentally Exposed Areas at Aswan, Egypt ,Environmental Bioindicators Journal, 2,( 2007), 131 - 145. http://dx.doi.org/10.1080/15555270701553972. 